\title{
Blood profile of broiler chickens fed supplemented garlic-based diets
}

Olumide, M. D. and Odunowo, O. O. Department of Animal Science, School of Agriculture and Industrial Technology,

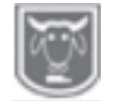

Abstract
Babcock University, Ilishan Remo, Ogun State. Nigeria.

Corresponding author: olumidem@babcock.edu.ng, olumidemartha@gmail.com

Conventional supplements have been criticised for their potential negative impact on the food chain. Poultry researchers and nutritionists have been searching for viable alternative feed additives. Poultry production is still facing challenges of diseases and a lot of research are still on going. This study was carried out to investigate the effects of garlic (Allium sativum) supplementation on the blood profile of broiler chicken. One hundred and fifty-day old Marshal strains of broiler chicken were assigned to five dietary treatments with thirty birds in a Completely Randomized Design. The thirty chicks were subdivided into three replicates of 10 birds each. Feed and water were offered ad libitum and mortality was recorded as it occurred. Blood were collected from two birds per replicate to determine haematological and serum biochemical responses. No significant $(p>0.05)$ difference was observed in the haematological response and serum biochemistry profile of broilers fed experimental diets, with the exception of the Cholesterol level which significantly $(p<0.05)$ decreased as the level of inclusion of the garlic increased, with the control diet having the highest value $(135.38 \mathrm{mg} / \mathrm{dL})$ while the least value $(129.80 \mathrm{mg} / \mathrm{dL})$ was obtained from diets containing $0.8 \%$ inclusion of garlic. Therefore, the inclusion of garlic (Allium sativum) in the diets of broiler chicken had no deleterious effects on the blood profile of the experimental birds but improved the cholesterol level of the birds at the inclusion level of $0.4 \mathrm{~g} /$ ton offeed.

Keywords: Marshal, Allium sativum, blood profile, supplementation, cholesterol, ad libitum.

\section{Introduction}

More emphasis than ever before is now placed on global food security. Poultry meat offers considerable potential for bridging the gap between supply and demand for animal protein, especially in Africa. Feed additives are added to poultry feed to improve nutritive value of ingredients and enhance broiler performance by increasing growth rate and improving feed conversion efficiency. Chemical feed additives such as antibiotic growth promoters (AGP) have been used intensively in broiler chicken ration to improve productivity; however, they are notorious for bacterial resistance and their negative impacts on the consumers' health (Rehman and Haq, 2014). Consequently, the use of Antibiotic Growth Promoters (AGPs) was banned in poultry industry; nutritionists are currently shifting from chemical growth promoter to phytogenic growth promoters. In a bid to discouraged poultry producers from using banned Antibiotic Growth Promoters (AGPs), it is important to explore the potential of innate feed additives to replace them. Herbs could be expected to serve as feed additives due to their suitability and preference, lower cost of production, reduced risk of toxicity, minimum health hazards and environment friendLiness (Devegowda; 1996). Garlic powder is a Phytogenic Feed Additive (PFA), which is a form of Natural Growth Promoters (NGP) frequently used in the Mediterranean region. Garlic (Allium sativum) contains about $17 \%$ protein, $0.8 \%$ fat, $3 \%$ minerals, with varying amounts of 


\section{Blood profile of broiler chickens fed supplemented garlic-based diets}

vitamins like thiamine, riboflavin, and niacin, and enzymes such as allinase, peroxidase, and myrosinase; in addition, it contains about $0.2 \%$ volatile oils, which are particularly released when the plant is processed into powder, which are used for various therapeutic purposes (Esmail; 2012). In most cases, chickens may however need some time to adapt to the powder in their diet before any beneficial effects are exhibited; this is mainly due to the oil fraction present in garlic powder which has a strong smell and unpleasant flavour. Since conventional supplements have been criticised for their potential negative impact on the food chain, poultry researchers and nutritionists have been searching for viable alternative feed additives. Among numerous poultry feed additives that are available for poultry nutrition, natural herbs and plants have been widely advocated due to their reported widespread beneficial effects on poultry health and productivity. Garlic (Allium sativum) is one such potential alternative feed additive which has recently been reported as having a wide range of beneficial effects on the production performance and physiological biochemistry of broilers and laying hens. Notable beneficial effects have been seen on growth, feed efficiency, egg production and quality, as well as stimulation of immune system (Qureshi et al; 1983). The results reported vary from author to author probably due to variations in the dose of the product fed, the duration of feeding and processing techniques employed. Garlic has anti-hypertensive, antimicrobial and antioxidant properties in humans and animals (Chen et al; 2008). Due to its antimicrobial properties, garlic is a highly studied medicinal plant used as growth promoter in broiler chickens. Garlic is not widely used as human food because it gives a repulsive odour and the taste is pungent. Since monogastric animals are able to incorporate dietary components directly in their tissues (Onibi et al., 2000), supplementary garlic for broilers could mediate in getting the bioactive compounds in garlic, through broiler meat into the human food chain, while avoiding the resentment due to its direct consumption. However, there is dearth of convincing information on quantity and form of supplementary garlic in broiler nutrition, hence the need to evaluate the effect of supplementation of garlic (Allium sativum) in the diets of broiler chickens on the blood profile.

\section{Materials and methods \\ Sourcing of experimental material}

Garlic cloves were sourced and purchased from the local markets between Ilara-Remo and Ilishan-Remo, Ogun state, Nigeria. The cloves were air-dried, milled with hammer mill and bagged prior to use. The ground Allium sativum was thoroughly mixed with the feed at the rate of $0.0 \mathrm{~g}, 0.0 \mathrm{~g}, 50 \mathrm{~g}, 100 \mathrm{~g}$ and $200 \mathrm{~g}$ per $25 \mathrm{~kg}$ bag of experimental feed.

\section{Experimental site}

The experiment was conducted at the Teaching and Research Farm of Department of Agriculture and Industrial Technology, Babcock University, IlishanRemo, Ogun State. Ilishan-Remo is in the rain forest of south western Nigeria with mean rainfall of $2400 \mathrm{~mm}$. Ilishan is in the south west geo-political zone of Nigeria and falls on latitude of $6^{\circ} 54^{\prime} \mathrm{N}$ from the equator and longitude $3^{\circ} 42^{\prime} \mathrm{E}$ from the Greenwich Meridian and the mean annual temperature is about $27^{\circ} \mathrm{C}$.

\section{Experimental birds and designs}

A total of 150, one-day old broiler chicks of Marshall Strain were procured from a reputable hatchery and bred for 7 weeks. On arrival, the birds were randomly assigned into five dietary treatments with three (3) replicates of 10 birds per replicate. Feed and 


\section{Olumide and Odunowo}

water were provided ad-libitum. The experimental design used was completely randomised design.

\section{Experimental diets}

The cloves were air-dried to remove moisture and then minced into a coarse texture. Five diets were formulated and compounded for the experiment with various inclusion levels of Allium sativum, except the positive control group (T1) which contained the antibiotic feed additive. They are as follows; T1 (+ Control) $-0.0 \%$ of garlic with antibiotics (oral), T2 (- control) $-0.0 \%$ of garlic without antibiotics (oral), T3 $-0.2 \%$ of garlic, T4 $-0.4 \%$ of garlic, T5 $-0.8 \%$ of garlic.

\section{Management of experimental birds}

The cages were washed and disinfected using a disinfectant and left to rest for two weeks prior to the arrival of the chicks. Before the arrival of the birds, the brooding cages were ready and water was waiting for them upon arrival. The experimental birds were vaccinated but not medicated due to the nature of the study to prevent interruption of data which might lead to experimental error.

\section{Blood collection, haematology and serum metabolites analysis}

At the end sixth week of feeding trials, two (2) birds from each dietary replicate were randomly sampled to determine haematological and serum biochemical responses. $5 \mathrm{ml}$ of blood were taken from the jugular vein of randomly selected birds per replicate. $2.5 \mathrm{ml}$ of sampled blood were put into labelled blood sample bottles containing anti-coagulant (Ethyl DiamineTetra-Acetate powder (EDTA)) to determine haematological parameters. Parameters analysed include; Packed Cell Volume (PCV) (\%), Haemoglobin (g/l),
Red Blood Cells (RBC) $\left(10^{6} \mathrm{ul}\right)$, White Blood Cell (WBC) $\left(10^{3} \mathrm{ul}\right)$, Lymphocytes (\%), Neutrophils (\%), Monocytes (\%), Eosinophil (\%) and Basophils (\%) according to the procedure of Howlett and Jamie (2008). The remaining $2.5 \mathrm{ml}$ of sampled blood were put into a well labelled sterile blood sample bottles without anticoagulant to determine serum biochemical parameters such as Glucose (mg/dL), Total Protein ( $/ \mathrm{dL})$, Albumin (g/dL), Cholesterol (mg/dL), Alanine transaminase (IU/L), Aspartate transaminase (IU/L) and Creatinine (mg/dL).

\section{Statistical analysis}

Significant treatment means were subjected to analysis of variance (ANOVA) using statistical analysis system package (SAS, 2002). Means were separated using Duncan multiple range test (Duncan, 1955).

\section{Results}

Table 1 and 2 showed the gross composition and determined analysis of experimental starter and finishers diets. In the starter diets, the value obtained for dry matter ranged from $88.26 \%$ - $90.80 \%$, the value obtained for crude protein ranged from $21.26 \%$ - $22.24 \%$ while the crude fibre value ranged from $2.49 \%-3.29 \%$, ash value ranged from $5.15 \%-6.85 \%$ and ether extract $2.00 \%-3.85 \%$. Treatment 1 and treatment 2 (control) recorded the highest crude protein value $(22.24 \%)$ while treatment $3(0.2 \%$ garlic) recorded the least value $(19.26 \%)$. Though these values do not differ significantly, they however differ from the calculated crude protein level of $21.29 \%$. The values obtained for the metabolizable energy ranged from 2788.54 $-2865.63 \mathrm{Kcal} / \mathrm{kg}$. The values obtained for the determined analysis were slightly different from that of the gross composition. 
Blood profile of broiler chickens fed supplemented garlic-based diets

Table 1: Composition of garlic supplemented starter diets

\begin{tabular}{llllll}
\hline & \multicolumn{5}{c}{ TREATMENTS } \\
\cline { 2 - 6 } INGREDIENTS (\%) & $\mathbf{0 . 0 \%}$ & $\mathbf{0 . 0 \%}$ & $\mathbf{0 . 2 \%}$ & $\mathbf{0 . 4 \%}$ & $\mathbf{0 . 8 \%}$ \\
\hline Maize & 57.50 & 57.50 & 57.50 & 57.50 & 57.50 \\
Soybean Meal & 34.00 & 34.00 & 34.00 & 34.00 & 34.00 \\
Garlic powder & 0.00 & 0.00 & 0.20 & 0.40 & 0.80 \\
Wheat Offal & 3.10 & 3.10 & 2.90 & 2.70 & 2.30 \\
Vegetable Oil & 1.00 & 1.00 & 1.00 & 1.00 & 1.00 \\
Bone Meal & 2.00 & 2.00 & 2.00 & 2.00 & 2.00 \\
Salt & 0.25 & 0.25 & 0.25 & 0.25 & 0.25 \\
Premix & 0.25 & 0.25 & 0.25 & 0.25 & 0.25 \\
L-Lysine & 0.10 & 0.10 & 0.10 & 0.10 & 0.10 \\
DL-Methionine & 0.20 & 0.20 & 0.20 & 0.20 & 0.20 \\
Limestone & 1.50 & 1.50 & 1.50 & 1.50 & 1.50 \\
Tox-nil & 0.10 & 0.10 & 0.10 & 0.10 & 0.10 \\
Total & $\mathbf{1 0 0 . 0 0}$ & $\mathbf{1 0 0 . 0 0}$ & $\mathbf{1 0 0 . 0 0}$ & $\mathbf{1 0 0 . 0 0}$ & $\mathbf{1 0 0 . 0 0}$ \\
Calculated analysis & & & & & \\
Crude Protein (\%) & 21.29 & 21.29 & 21.29 & 21.29 & 21.29 \\
Crude Fibre (\%) & 3.64 & 3.64 & 3.63 & 3.61 & 3.58 \\
Metabolizable Energy(Kcal/Kg) & 3024.60 & 3024.60 & 3028.21 & 3031.82 & 3039.05 \\
Determined analysis & & & & & \\
Dry matter & 89.36 & 89.36 & 89.48 & 90.80 & 88.26 \\
Crude protein (\%) & 22.24 & 22.24 & 21.26 & 21.72 & 21.79 \\
Crude fibre (\%) & 3.29 & 3.29 & 2.69 & 2.60 & 2.49 \\
Ether extract (\%) & 2.70 & 2.70 & 3.60 & 3.70 & 3.85 \\
Ash (\%) & 6.85 & 6.85 & 5.15 & 6.85 & 5.60 \\
Metabolizable Energy (Kcal/Kg) & 2788.54 & 2788.54 & 2749.40 & 2814.48 & 2865.63 \\
\hline
\end{tabular}

While in the finisher diets, the value obtained for dry matter ranged from $90.60 \%-91.66 \%$, the value obtained for crude protein ranged from $19.00 \%$ $19.95 \%$, while that of crude fibre ranges from $3.19 \%$ - 3.99\%, and the values obtained for ether extract were between $3.60 \%-3.75 \%$, ash content of the experimental diet ranged from $5.11 \%$ $6.85 \%$. Treatment 5 (0.8\% garlic) recorded the highest crude protein value (19.95\%) while treatment $3(0.2 \%$ garlic $)$ recorded the least value $(19.00 \%)$. Though these values did not differ significantly, they however differed from the calculated crude protein level of $20.23 \%$. The metabolizable energy values obtained ranged from 2874.78 - $2998.49 \mathrm{Kcal} / \mathrm{kg}$. The values obtained for the determined analysis of the finisher diets differ from the gross
analysis.Table 3 showed the haematological response of broiler chicken fed experimental diets supplemented with garlic. The parameters analysed include; Packed Cell Volume (PCV) (\%), Haemoglobin (Hb) (g/l), Red Blood Cells (RBC) $\left(10^{3} \mathrm{ul}\right)$, White Blood Cell (WBC) $\left(10^{3} \mathrm{ul}\right)$, Lymphocytes (\%), Neutrophils (\%), Monocytes (\%), Eosinophil (\%) and Basophils (\%). The value obtained for Packed Cell Volume ranged from $24.00-26.80 \%$, while that of Haemoglobin ranged from $7.78-8.30 \mathrm{~g} / \mathrm{dL}$, the value obtained for Red Blood Cells ranged from $3.06-3.96\left(10^{3} \mathrm{ul}\right)$, White Blood Cell count of the experimental birds ranged from $16.88-17.85\left(10^{3} \mathrm{ul}\right)$, the value obtained for Lymphocytes ranged from $62.25-64.17 \%$, while that of Neutrophils ranged from $26.50-29.17 \%$, the value 


\section{Olumide and Odunowo}

obtained for Monocytes ranged from $3.17-$ $3.83 \%$, while that of Eosinophil ranged

for Basophils were between $0.17-0.67 \%$. from $3.17-3.83 \%$ and the values obtained

No significant differences were observed in the parameters measured.

Table 2: Composition of garlic supplemented finisher diets

\begin{tabular}{llllll}
\hline & \multicolumn{5}{c}{ TREATMENTS } \\
\cline { 2 - 6 } INGREDIENTS (\%) & $\mathbf{0 . 0 \%}$ & $\mathbf{0 . 0 \%}$ & $\mathbf{0 . 2 \%}$ & $\mathbf{0 . 4 \%}$ & $\mathbf{0 . 8 \%}$ \\
\hline Maize & 53.00 & 53.00 & 53.00 & 53.00 & 53.00 \\
Soybean Meal & 29.00 & 29.00 & 29.00 & 29.00 & 29.00 \\
Garlic & 0.00 & 0.00 & 0.20 & 0.40 & 0.80 \\
Wheat Offal & 12.60 & 12.60 & 12.40 & 12.20 & 11.80 \\
Vegetable Oil & 1.00 & 1.00 & 1.00 & 1.00 & 1.00 \\
Bone Meal & 2.00 & 2.00 & 2.00 & 2.00 & 2.00 \\
Salt & 0.25 & 0.25 & 0.25 & 0.25 & 0.25 \\
Premix & 0.25 & 0.25 & 0.25 & 0.25 & 0.25 \\
Lysine & 0.10 & 0.10 & 0.10 & 0.10 & 0.10 \\
Methionine & 0.20 & 0.20 & 0.20 & 0.20 & 0.20 \\
Limestone & 1.50 & 1.50 & 1.50 & 1.50 & 1.50 \\
Tox-nil & 0.10 & 0.10 & 0.10 & 0.10 & 0.10 \\
Total & 100.00 & 100.00 & 100.00 & 100.00 & 100.00 \\
Calculated analysis & & & & & \\
Crude Protein (\%) & 20.23 & 20.23 & 20.23 & 20.23 & 20.23 \\
Crude Fibre (\%) & 3.98 & 3.98 & 3.97 & 3.95 & 3.92 \\
Metabolizable Energy(Kcal/Kg) & 2914.25 & 2914.25 & 2917.86 & 2921.47 & 2928.70 \\
Determined analysis & & & & & \\
Dry matter & 90.60 & 90.60 & 91.13 & 91.24 & 91.66 \\
Crude protein (\%) & 19.70 & 19.70 & 19.00 & 19.88 & 19.95 \\
Crude fibre (\%) & 3.99 & 3.99 & 3.45 & 3.39 & 3.19 \\
Ether extract (\%) & 3.60 & 3.60 & 3.62 & 3.70 & 3.75 \\
Ash & 6.85 & 6.85 & 5.45 & 5.35 & 5.11 \\
Metabolizable Energy(Kcal/Kg) & 2949.48 & 2949.48 & 2998.09 & 2952.38 & 2874.78 \\
\hline
\end{tabular}

Table 3: Haematological responses of broiler chicken fed garlic supplemented diet

\begin{tabular}{|c|c|c|c|c|c|c|c|}
\hline \multirow[b]{2}{*}{ PARAMETERS } & \multicolumn{5}{|c|}{ TREATMENTS } & \multirow[b]{2}{*}{ RANGE } & \multirow[b]{2}{*}{ SEM } \\
\hline & T1 & T2 & T3 & T4 & T5 & & \\
\hline Packed Cell Volume (\%) & 24.00 & 24.33 & 24.83 & 25.95 & 26.80 & $24.9-45.2$ & 0.45 \\
\hline Haemoglobin (g/dL) & 8.00 & 7.78 & 7.95 & 8.15 & 8.30 & $7.40-13.1$ & 0.15 \\
\hline Red Blood Cells ( $\left.10^{3} \mathrm{ul}\right)$ & 3.06 & 3.12 & 3.25 & 3.38 & 3.96 & $1.58-4.10$ & 0.80 \\
\hline White Blood Cells $\left(10^{3} \mathrm{ul}\right)$ & 16.88 & 17.00 & 17.85 & 17.55 & 17.49 & $9.20-31.0$ & 21.66 \\
\hline Lymphocytes $(\%)$ & 62.25 & 62.17 & 62.67 & 64.17 & 64.17 & $43.9-67.7$ & 0.89 \\
\hline Neutrophils (\%) & 26.50 & 28.83 & 29.17 & 28.33 & 26.67 & $15.6-32.8$ & 0.94 \\
\hline Monocytes (\%) & 3.50 & 3.50 & 3.33 & 3.17 & 3.83 & $0.06-9.10$ & 0.20 \\
\hline Eosinophil (\%) & 3.25 & 3.50 & 3.17 & 3.83 & 3.17 & $6.25-9.66$ & 0.24 \\
\hline Basophils (\%) & 0.50 & 0.50 & 0.67 & 0.33 & 0.17 & $2.50-5.36$ & 0.12 \\
\hline
\end{tabular}

SEM: Standard Error of Means. 
Blood profile of broiler chickens fed supplemented garlic-based diets

Table 4: Serum biochemical responses of broiler chicken fed garlic supplemented diets

\begin{tabular}{|c|c|c|c|c|c|c|c|}
\hline \multirow[b]{2}{*}{ PARAMETERS } & \multicolumn{5}{|c|}{ TREATMENTS } & \multirow[b]{2}{*}{ RANGE } & \multirow[b]{2}{*}{ SEM } \\
\hline & T1 & T2 & T3 & T4 & T5 & & \\
\hline Total Protein $(\mathrm{g} / \mathrm{dL})$ & 3.46 & 3.65 & 3.91 & 4.26 & 4.08 & $5.20-6.90$ & 0.09 \\
\hline Albumin (mg/dL) & 1.69 & 1.71 & 1.52 & 1.67 & 1.80 & $2.10-3.45$ & 0.08 \\
\hline Cholesterol (mg/dL) & $135.38^{\mathrm{a}}$ & $135.37^{\mathrm{a}}$ & $134.18^{\mathrm{a}}$ & $131.41^{\mathrm{b}}$ & $129.80^{\mathrm{b}}$ & $52.0-148$ & 1.80 \\
\hline Glucose (mg/dL) & 68.84 & 57.33 & 91.22 & 86.83 & 89.11 & $152-182$ & 5.20 \\
\hline Creatinine (mg/dL) & 1.02 & 1.07 & 1.01 & 0.98 & 0.95 & $0.90-1.85$ & 0.04 \\
\hline Aspartate transaminase (I.U/L) & 84.61 & 99.60 & 104.36 & 94.94 & 86.32 & $88.0-208$ & 3.92 \\
\hline Alanine transaminase (I.U/L) & 5.68 & 5.70 & 5.81 & 7.06 & 5.90 & $9.50-37.2$ & 1.04 \\
\hline
\end{tabular}

a b Means on the same row having with superscripts are significantly different $(\mathrm{P}<0.05)$.

SEM: Standard Error of Means.

Table 4 showed the serum biochemistry of broiler birds fed diets supplemented with garlic. The serum biochemical parameters analysed include; total protein $(\mathrm{g} / \mathrm{dL})$, albumin $(\mathrm{mg} / \mathrm{dL})$, cholesterol $(\mathrm{mg} / \mathrm{dL})$ glucose $(\mathrm{mg} / \mathrm{dL})$, creatinine $(\mathrm{mg} / \mathrm{dL})$, aspartate transaminase (IU/L), and Alanine transaminase (IU/L).

The values obtained for total protein of the experimental birds ranged from $3.46-4.26$ $\mathrm{g} / \mathrm{dL}$, the value obtained for albumin ranged from $1.52-1.80 \mathrm{mg} / \mathrm{dL}$, while that of cholesterol values ranged from $129.80-$ $135.38 \mathrm{mg} / \mathrm{dL}$, glucose ranged from 57.33 $91.22 \mathrm{mg} / \mathrm{dL}$ and the values obtained for creatinine were between $0.95-1.02 \mathrm{mg} / \mathrm{dL}$ while that of aspartate transaminase ranged from $84.61-104.36 \mathrm{IU} / \mathrm{L}$, the value obtained for alanine transaminase ranged from $5.68-7.06 \mathrm{IU} / \mathrm{L}$. All the values obtained for the serum biochemistry were not significantly different except that obtained from the cholesterol.

\section{Discussion}

In the starter diet, the highest dry matter percentage $(90.80 \%)$ obtained was for the diet containing $0.4 \%$ (T4) inclusion level of the test ingredient, garlic (Allium sativum) while the least value obtained for dry matter was from the diet containing $0.8 \%$ inclusion level of garlic. The highest Crude Protein value (CP), crude fibre and ash were obtained from Treatment 1 and Treatment 2 $(0.0 \%$ inclusion level of garlic) with and without antibiotics respectively while Treatment 5 ( $0.8 \%$ inclusion level of garlic) recorded the least value for Crude Fibre (CF), Ether Extract (EE) and ash. The highest value obtained for $\mathrm{CP}$ was obtained from the control diet while the value obtained for other diets did not follow a particular trend. These values were however lower than $(23.00 \%)$ recommended by NRC (1994). The metabolizable energy values obtained ranged from $2788.54-2865.63 \mathrm{Kcal} / \mathrm{kg}$. The result obtained in the proximate analysis of the experimental diet could be linked to the fact that the test ingredient has the same $\mathrm{CP}$ value with the wheat offal that was used in substituting for it in the gross composition therefore no significant difference was observed in the values of the proximate analysis. In the finisher diet, the highest dry matter percentage $(91.66 \%)$ was obtained from treatment $5 \quad(0.8 \%$ inclusion level of garlic) while the least $(90.60 \%)$ was obtained from treatment 1 and treatment $2(0.0 \%$ inclusion level of garlic) with and without antibiotics, respectively. While the least value of Crude Fibre of 3.19 was obtained from treatment 5 and ash value was obtained from treatment $5(0.8 \%$ inclusion level of garlic), In contrast, it also recorded the highest value for Ether Extract (3.75) compared with control diets $\mathrm{T} 1$ and $\mathrm{T} 2$ (3.60). The metabolizable energy (ME) showed no significant difference and ranged from 


\section{Olumide and Odunowo}

2874.78 - 2998.09. The highest value obtained for CP was obtained from treatment 5 ( $0.8 \%$ inclusion level of garlic) while the value obtained for other diets did not follow a particular trend. All the values of proximate analysis obtained from these experimental diets were not significantly different $(\mathrm{P}>0.05)$. The values obtained for the finisher diet were in line with recommendation of NRC (1994) for broiler production. The result for the Packed Cell Volume, haemoglobin and Red Blood Cells although not significantly different among treatment but showed that as the level of inclusion of test ingredient increased, the value obtained for those parameters increased. According to Isaac et al. (2013); Packed Cell Volume is involved in the transport of oxygen and absorbed nutrients. Increased Packed Cell Volume shows a better transportation and thus prevents anaemia (Coles; 1986). This result was also in line with the report of Chineke et al. (2006) which states that Packed Cell Volume readily indicated an increase in the number of Red Blood Cells or reduction in circulatory Plasma Volume. The result of Packed Cell Volume and haemoglobin which increases as the inclusion level of garlic increase in the diets is in accordance with Adejumo (2004) who reported that Packed Cell Volume and haemoglobin were positively correlated with the nutritional status of animal. Higher White Blood Cells (WBC) obtained from birds fed garlic supplemented diet compared to the control could probably be attributed to absences of anti-nutrients in the test ingredients. This is further collaborated by the higher lymphocyte count of the birds on these diets compared with the control diet. It has been reported that toxic substances in feed tends to suppress haemopoietic tissues with consequent lower production of White Blood Cells. This observation however implies that the diets supported haemopoietic tissue with production of adequate White Blood Cells. Thus result indicated that the immune system of the birds was not compromised because the White Blood Cells function primarily as defence system in the body (Eroschenko, 2000) as values obtained for Neutrophils, Monocytes Eosinophils and basophils were within the normal range for healthy birds (Mitruka and Rawsley, 1977; Archetti et al., 2008).

It was reported by Frandson (1986) that the number of neutrophils in the blood increases rapidly when acute infection is present; hence a blood count showing this increase is useful in diagnosis of infections, which was in contrary in this result. The low values of monocytes and basophils agreed with the statement that basophils and monocytes are normally present in small to moderate number in the blood system. There was no significant $(\mathrm{P}>0.05)$ difference between the serum biochemical parameters of birds fed experimental diets except for Cholesterol values. The nonsignificant effect of experimental diets on the total protein and albumin of the birds indicate the ability of the diets to support production of these blood components. Total protein and creatinine contents have been shown to depend on the quantity and quality of dietary protein. (Iyayi) 1998; Esonu et al. 2001). The values obtained for albumin in this study were lower than the recommended value from Mitruka and Rawsley (1977). The lower values of albumin results obtained in this study could result in poor blood clothing; hence birds can be prone to haemorrhages. The cholesterol level in this study was significantly affected by the dietary treatment and as the inclusion level of garlic in the diet increases, the cholesterol value decreases. However, values are within the range of normal healthy chicken (Mitruka and Rawsley, 1977). The finding of this 


\section{Blood profile of broiler chickens fed supplemented garlic-based diets}

study agrees with the result of Mansoub (2011) who reported reductions in total cholesterol when broilers were supplemented with $1 \mathrm{~g} / \mathrm{kg}$ garlic. This results also tallies with Stanacev et al. (2011) who reported that garlic manifested hypocholesterolemic effects on chickens through inhibition of the most important enzymes that participate in the synthesis of cholesterol and lipids.

According to Qureshi et al. (1983) Allicin (diallyl thiosulfinate, a volatile organic compound containing sulphur), presumed to be the active ingredient of garlic extract has been shown to suppress cholesterol biosynthesis in chickens. Since the cholesterol levels were within the normal range, possibilities of anorexia, liver dysfunction and malabsorption of fat which are the symptoms of abnormal cholesterol levels in the blood are ruled out. The values obtained for glucose in this study were below the recommended value (Mitruka and Rawsley, 1977). Creatinine had values ranging from $0.95-1.02 \mathrm{mg} / \mathrm{dL}$. The control diet had the highest creatinine value of $1.02 \mathrm{mg} / \mathrm{dL}$, while the least value $(0.95 \mathrm{mg} / \mathrm{dL})$ was obtained from birds on T5. This implies the nutritional superiority of the protein quality (Aning et al., 1998). Creatinine is also linked with muscle wasting as a result of excess creatinine in the blood of animals due to catabolism (Bell et al., 1992), this is ruled out in the present study.

Aspartate transaminase (AST) and alanine transaminase (ALT) (I.U/L) values were similar among the dietary groups. The values obtained for Aspartate transaminase were within the recommended value for chicken by Mitruka and Rawsley (1977) while those obtained for Alanine transaminase were below the recommended values for chicken by Mitruka and Rawsley (1977). The result obtained from the
Aspartate transaminase obtained from the birds fed experimental diets did not follow any particular trend, although the concentrations are within the normal range of $88.0-208.1 \mathrm{U} / \mathrm{L}$ reported for chicken (Mitruka and Rawsley, 1977). An increase in serum Aspartate transaminase and Alanine transaminase above normal range has been reported to signify necrosis and myocardial infection or response to the presence of toxic factors. From the results there is clear evidence that the test ingredient compared favourably in all serum biochemical indices evaluated.

\section{Conclusion}

This study revealed that garlic (Allium sativum) could be used in the diets of broiler chicken at various inclusion levels without any deleterious effect on the haematology and serum biochemistry but improved the cholesterol level of the birds at the inclusion level of $0.8 \% /$ ton of feed.

\section{References}

Adejumo, D. O. 2004. Performance, organ development and haematological of rats fed sole diets of graded levels of cassava flour and soybean flour (Soygari) as substitutes for energy and protein concentrates. Trop. J. Anim. Sci., 7: 57-63

Aning, K. G., Ologun, A. G., Onifade, A., Alokan, J. A., Adekola, A. I., Aletor, V.A.1998. Effect of replacing dried brewers dried grains with sorghum rootlets on g r o w i n g n t rie n t s utilization and some blood constituents in rats. Animal Feed sci. Technol. 71:185-190.

Archetti, I., Tittarelli, C., Ceriolo, M., Brivio, R., Grilli, G. and Lavazza, A. 2008. Serum chemistry and haematology values in commercial rabbits: 


\section{Olumide and Odunowo}

preliminary data from industrial farms in Northern Italy. Proceedings of $9^{\text {th }}$ the World Rabbit Congress, Italy, pp $\quad 1147$ 1151.

Association of Analytical Chemists. 1990. Official methods of analysis.15th edition. AOAC, Washington, DC. USA.

Bell, G. H., Enslie-Smith, D. and Patterson, C. R. 1992. Textbook of Physiological biochemistry. Churchill Livingstone, Edinburgh, pp 229-230

Chen, Y., Kim, I., Cho, J., Yoo, J., Wang, Q., Wang, Y. and Huang, Y. 2008. 'Evaluation of dietary carnitine of garlic powder on growth performance, dry matter and nitrogen digestibility, blood profiles and meat quality in finishing pigs'. Animal Feed Science, Tech; 141: 141-152.

Chineke, C. A., Ologun, A. G. and Ikeobi, C. O. 2006. Haematological parameters in rabbit breeds and crosses in humid tropics. PakJ Biol. Sci. 9:2102-2106.

Coles, E. H. 1986. Veterinary clinical pathology, $4^{\text {th }}$ ed. W.B Saunder Company, Philadelphia; 72 -163 .

Devegowda, G. 1998 'Herbal medicinesAn untapped treasure in poultry production'. xx world's poultry congress, New Delhi, 11: 135-140.

Duncan, D. B. 1955 'Multiple range and multiple F test,' Biometrics, vol. 11, pp. 1-42.

Eroschenko, V. P. 2000. Di Fiore's Atlas of Histology with Functional Correlations, 9th ed. Lippincott Williams and Wilkins, USA.

Esmail, S. H. 2012. Analytics, Black cumin and garlic powder in poultry diets In: World
(7), p. 7-9.

Esonu, B. O., Emenalom, O. O., Udedibie, A. B. I., Herbert, U., Ekpor, C. F., Okoli, I. and Iheukwumere, F. C. 2001. Performance and blood chemistry of weaner pigs fed raw mucuna beans (velvet bean) meal. Trop. Anim. Production Invest. 4: 49-54.

Frandson, R. D. 1986. Anatomy and physiology of farm animals. $4^{\text {th }}$ Edition, Lea and Fibiger Publishers. 600 Washington square, Philadelphia P.A. 19106-41980 USA (215). Pg. 92.1330.

Isaac, L. J., Abah, G., Akpan, B. and Ek a e t t e, I. U . 2013 . Haematological Properties of Different Breeds and Sexes of Rabbits. Proceedings of the 18th Annual Conference of Animal Science Association of Nigeria, 2427.

Iyayi, E. A. and Tewe, O. O. 1998. Serum total protein urea and creatinine levels as indices of quality of cassava diet for pigs. Tropical Vetenarian, 36:59-67.

Mansoub, N. H. 2011. Comparative effects of using garlic as probiotic on performance and $\mathrm{se} \mathrm{r} \mathrm{u} \mathrm{m}$ composition of broiler chickens. Annals of biological Research, 2, 486 - 490.

Mitruka, B. T. and Rawsley, H. 1977. Clinical, biochemical and haematological reference value in normal experimental animals. Mason publishing, N.Y., U.S.A.,pp. 171-174.

Nutrient Requirements of Poultry 1994. Ninth Revised Edition, National Research Council.

Onibi, G. E., Scaife, J. R., Murray, I. and F o w l e r, V. R. 2000 . 
'Supplementary tocopherol acetate in full fat rape seed-based diets for pigs. Influence on tissue tocopherol content, fatty a c i d profile and lipid oxidation. $J$. Sci. Food Agric. 80:1625-1632.

Qureshi, A. A., Din, Z. Z., Abuirmeileh, N., Burger, W. C., Ahmad, Y. and Elson, C. E. $\quad \begin{array}{llllll}1 & 9 & 8 & 3\end{array}$. Suppression of avian hepatic lipid metabolism by solvent extracts of garlic: impact on serum lipids. $J$. Nutr. 113: 1746-1755.

Qureshi, A. A., Abuirmeileh, N., Din, Z. Z., Elson, C. E. and Burger, W. C. 1983 . In hibition of cholesterol and $\mathrm{f}$ a t t y a c i d biosynthesis in liver enzymes and chickenhepatocytes by $\mathrm{p}$ o $1 \mathrm{ar}$ fractions of garlic. Lipids 18, 343348 .
Rehman, Z., and Haq, A. 2014. 'Effect of garlic and ginger supplementation on broiler performance'. Lambert Publishing Company.

SAS. 2002. User's Guide Statistics version, $10^{\text {th }}$ edition, SAS statistical package Inc, cary, $\quad \mathrm{N}$ o r t h Carolina, U.S.A.

Stanacev, V., Glamoci, D., Miloševic, N., Puvacac, N., Stanacev, V. and Plavša N. 2011. Effect of garlic (Allium sativum l.) in fattening chicks Nutrition. African Journal of Agricultural Research, 6(4), 943-948.

Received: $17^{\text {th }}$ April, 2019

Accepted: $25^{\text {th }}$ July, 2019 